Journal of Clinical Investigation

Vol. 42, No. 8, 1963

\title{
MUTUAL SUPPRESSION OF THE URICOSURIC EFFECTS OF SULFINPYRAZONE AND SALICYLATE: A STUDY IN INTERACTIONS BETWEEN DRUGS *
}

\author{
By T. F. YÜ, P. G. DAYTON, ANd A. B. GUTMAN \\ (From the Department of Medicine, The Mount Sinai Hospital, and the New York University \\ Research Service, Goldwater Memorial Hospital, New York, N. Y.)
}

(Submitted for publication March 1, 1963 ; accepted May 2, 1963)

A striking example of antagonistic drug effects (2) is afforded by the observation that in man salicylate, itself uricosuric in high dose, inhibits the pronounced uricosuria produced by probenecid $(3,4)$, sulfinpyrazone ${ }^{1}(5-9)$, and zoxazolamine (9-11). This suppressive action of salicylate has been assumed to be due to its successful competition with these drugs, and with uric acid, for renal tubular transport; one aspect of this competition is expressed as inhibition of tubular secretion of uric acid by small (and large) doses of salicylate, which partially counterbalances the inhibition of tubular reabsorption of uric acid produced by uricosuric agents (12). The present study provides experimental support for the operation of these mechanisms, but indicates that the interactions at least of salicylate and sulfinpyrazone are even more complex, involving competition also for binding sites on transporting plasma proteins, and possibly elsewhere. The consequences of the interplay of competition at these various sites are described in man, and also in the dog, in which mutual suppression of the uricosuric effects of sulfinpyrazone and salicylate, so apparent in man, could not be demonstrated.

\section{METHODS}

The standard renal clearance techniques previously employed $(13,14)$ were used. The studies in man were all made in gouty males. In six experiments (in five men), after three or four 15-minute control periods, sulfinpyrazone was infused, $300 \mathrm{mg}$ to prime and $10 \mathrm{mg}$ per minute to sustain. After 30 to 40 minutes for equilibration, the ensuing plasma and urinary sulfinpyrazone and uric acid

* This work was supported in part by U. S. Public Health Service grants (A-162 and A-4724) and by the Health Research Council of the City of New York under contract U-1089. Preliminary results have been reported in abstract (1).

1 1,2-Diphenyl-4-(2-phenylsulfinylethyl)-3,5-pyrazolid nedione. concentrations were measured over three or four 10 minute collection periods. With the sustaining sulfinpyrazone infusion continued at the same rate, sodium salicylate was then infused concurrently, $3 \mathrm{~g}$ to prime and 10 to 20 $\mathrm{mg}$ per minute to sustain. The collection periods were continued for about 1 hour. Two of the five men (NG and ER) received sodium bicarbonate together with the salicylate to allow study of the effect of alkalinization of the urine.

Three companion experiments in men followed the same procedure except for reversal of the order of infusion: sodium salicylate was given first, and then sulfinpyrazone, both in the same dosages as before. For analysis in greater detail of the effect of salicylate upon the plasma concentrations of sulfinpyrazone ( $\left.\mathrm{P}_{\mathbf{S P z}}\right)$, a ninth man was given $800 \mathrm{mg}$ iv sulfinpyrazone first, then $3 \mathrm{~g}$ of sodium salicylate 1 hour later, and blood samples were taken every 30 minutes.

Parallel studies were made in dogs, each receiving throughout a urate infusion at the rate of 5 to $10 \mathrm{mg}$ per minute. In four mongrel and two Dalmatian dogs, sulfinpyrazone was infused first, $300 \mathrm{mg}$ to prime and $1.6 \mathrm{mg}$ per minute to sustain, and then sodium salicylate, $1 \mathrm{~g}$ to prime and 10 to $20 \mathrm{mg}$ per minute to sustain. Two mongrels and three Dalmatians received the same infusions in reverse order. For investigation of any paradoxical effect of salicylate on uric acid excretion in the dog, two mongrels and two Dalmatians were given sodium salicylate infusions at a slowly increasing rate, as previously described in man (12). For study in greater detail of the effect of salicylate on $\mathrm{P}_{\mathbf{S P z}}$ in the dog, a mongrel was given $500 \mathrm{mg}$ iv sulfinpyrazone and 1 hour later, $2 \mathrm{~g}$ iv sodium salicylate.

The glomerular filtration rate (GFR) was measured in man as the clearance of inulin $\left(C_{i n}\right)$ determined by a resorcinol method (15), and in the dog as the exogenous creatinine clearance $\left(\mathrm{C}_{\mathrm{cr}}\right)$, determination of creatinine, by the method of Bonsnes and Taussky (16). Uric acid was estimated by differential spectrophotometry (17), and plasma and urinary salicylate by the method of Brodie, Udenfriend, and Coburn (18). Plasma and urinary sulfinpyrazone was estimated by the method of Burns and associates (5), with the following modifications. After extraction of the drug into ethylene dichloride, the organic phase was washed once with an equal volume of $0.1 \mathrm{M}$ citrate- $0.2 \mathrm{M}$ disodium phosphate buffer at $\mathrm{pH}$ 4.8, and then with $5 \mathrm{ml}$ of buffer. This removes interfering substances, including salicylate and its oxidation 
TABLE I

Interactions of sulfinpyrazone (SPZ) and salicylate (SAL) in man*

\begin{tabular}{|c|c|c|c|c|c|c|c|c|c|c|c|c|c|c|c|c|c|}
\hline \multirow{2}{*}{$\begin{array}{l}\text { Sub- } \\
\text { ject }\end{array}$} & \multirow[b]{2}{*}{ Period } & \multirow[b]{2}{*}{ Infusion } & \multirow[b]{2}{*}{$C_{\text {in }}$} & \multicolumn{4}{|c|}{ Urate } & \multicolumn{4}{|c|}{ Sulfinpyrazone } & \multicolumn{4}{|c|}{ Salicylate } & \multicolumn{2}{|c|}{ Urine } \\
\hline & & & & $\mathbf{P}$ & UV & $\mathrm{C}$ & $\mathrm{C}_{\mathrm{ur}} / \mathrm{C}_{\text {in }}$ & Ptotal & Prreet & F & UV & Ptotal & Pireet & $F$ & UV & $\mathrm{pH}$ & V \\
\hline & $\min$ & & $m l / m i n$ & $\begin{array}{c}m g / \\
100 \mathrm{ml}\end{array}$ & $\underset{m i n}{\operatorname{mg} /}$ & $\begin{array}{l}m l / \\
m i n\end{array}$ & $\%$ & $m g / 1$ & $100 \mathrm{ml}$ & $m g / r$ & $\min$ & $m g / 10$ & $00 \mathrm{ml}$ & $m g$ & $/ \min$ & & $\mathrm{ml} / \mathrm{min}$ \\
\hline $\mathrm{GH}$ & $\begin{array}{l}30-60 \\
70-140\end{array}$ & $\begin{array}{l}\mathrm{O} \\
\mathbf{S P Z} \\
\mathrm{SAL}\end{array}$ & $\begin{array}{l}171 \\
167 \\
158\end{array}$ & $\begin{array}{r}10.0 \\
9.4 \\
9.4\end{array}$ & $\begin{array}{l}1.27 \\
6.60 \\
1.26\end{array}$ & $\begin{array}{l}12.7 \\
70.0 \\
13.4\end{array}$ & $\begin{array}{r}7.4 \\
42.0 \\
8.5\end{array}$ & $\begin{array}{l}3.7 \\
2.1\end{array}$ & $\begin{array}{l}0.08 \\
0.15\end{array}$ & $\begin{array}{l}0.13 \\
0.23\end{array}$ & $\begin{array}{l}1.08 \\
1.05\end{array}$ & 16.9 & 5.18 & 8.0 & 1.07 & $\begin{array}{l}6.3 \\
6.5 \\
6.5\end{array}$ & $\begin{array}{l}4.5 \\
6.6 \\
8.8\end{array}$ \\
\hline MK & $\begin{array}{c}40-71 \\
103-149\end{array}$ & $\begin{array}{l}\mathrm{O} \\
\mathrm{SPZ} \\
\mathrm{SAL}\end{array}$ & $\begin{array}{l}142 \\
111 \\
111\end{array}$ & $\begin{array}{r}11.6 \\
9.4 \\
9.3\end{array}$ & $\begin{array}{l}1.91 \\
6.12 \\
1.24\end{array}$ & $\begin{array}{l}16.5 \\
65.2 \\
13.3\end{array}$ & $\begin{array}{l}11.6 \\
58.7 \\
12.0\end{array}$ & $\begin{array}{l}4.9 \\
2.9\end{array}$ & $\begin{array}{l}0.10 \\
0.20\end{array}$ & $\begin{array}{l}0.11 \\
0.22\end{array}$ & $\begin{array}{l}0.26 \\
0.51\end{array}$ & 22.5 & 6.8 & 7.5 & 0.37 & $\begin{array}{l}6.2 \\
6.4 \\
6.4\end{array}$ & $\begin{array}{l}14.6 \\
11.1 \\
14.3\end{array}$ \\
\hline \multirow[t]{2}{*}{ FA } & $\begin{array}{c}32-72 \\
141-197\end{array}$ & $\begin{array}{l}\mathrm{O} \\
\mathrm{SPZ} \\
\mathrm{SAL}\end{array}$ & $\begin{array}{l}63 \\
63 \\
63\end{array}$ & $\begin{array}{l}9.9 \\
9.5 \\
9.1\end{array}$ & $\begin{array}{l}0.63 \\
3.66 \\
1.60\end{array}$ & $\begin{array}{r}6.4 \\
38.5 \\
17.6\end{array}$ & $\begin{array}{l}10.2 \\
61.0 \\
28.0\end{array}$ & $\begin{array}{l}4.1 \\
3.1\end{array}$ & $\begin{array}{l}0.08 \\
0.22\end{array}$ & $\begin{array}{l}0.05 \\
0.14\end{array}$ & $\begin{array}{l}0.69 \\
0.66\end{array}$ & 21.0 & 7.0 & 4.4 & 0.28 & & $\begin{array}{l}3.0 \\
6.8 \\
6.1\end{array}$ \\
\hline & $\begin{array}{l}30-62 \\
75-135\end{array}$ & $\begin{array}{c}\mathrm{O} \\
\mathrm{SPZ} \\
\mathrm{S} A \mathrm{~L}\end{array}$ & $\begin{array}{l}66 \\
66 \\
70\end{array}$ & $\begin{array}{r}10.3 \\
10.0 \\
9.4\end{array}$ & $\begin{array}{l}0.73 \\
3.48 \\
2.04\end{array}$ & $\begin{array}{r}7.1 \\
34.8 \\
21.7\end{array}$ & $\begin{array}{l}10.8 \\
52.7 \\
31.0\end{array}$ & & & & & 22.3 & 7.4 & 5.2 & 0.58 & $\begin{array}{l}7.1 \\
7.4 \\
7.3\end{array}$ & $\begin{array}{l}4.0 \\
5.2 \\
7.4\end{array}$ \\
\hline ER & $\begin{array}{c}30-92 \\
105-175 \\
175-223\end{array}$ & $\begin{array}{c}\mathrm{O} \\
\mathrm{SPZ} \\
\mathrm{SAL}+ \\
\mathrm{NaHCO}_{3}\end{array}$ & $\begin{array}{l}154 \\
153 \\
151 \\
153\end{array}$ & $\begin{array}{l}9.4 \\
9.0 \\
8.2 \\
8.5\end{array}$ & $\begin{array}{l}0.72 \\
5.26 \\
1.27 \\
1.33\end{array}$ & $\begin{array}{r}7.7 \\
58.5 \\
15.5 \\
15.7\end{array}$ & $\begin{array}{r}5.0 \\
38.2 \\
10.3 \\
10.3\end{array}$ & $\begin{array}{l}2.9 \\
0.9 \\
0.9\end{array}$ & $\begin{array}{l}0.06 \\
0.06 \\
0.06\end{array}$ & $\begin{array}{l}0.10 \\
0.10 \\
0.10\end{array}$ & $\begin{array}{l}1.18 \\
0.77 \\
0.80\end{array}$ & $\begin{array}{l}21.8 \\
21.4\end{array}$ & $\begin{array}{l}6.5 \\
6.4\end{array}$ & $\begin{array}{l}9.8 \\
9.8\end{array}$ & $\begin{array}{l}2.88 \\
3.93\end{array}$ & $\begin{array}{l}7.0 \\
7.1 \\
7.4 \\
7.6\end{array}$ & $\begin{array}{l}12.3 \\
11.1 \\
12.8 \\
13.8\end{array}$ \\
\hline NG & $\begin{array}{r}37-103 \\
146-193\end{array}$ & $\begin{array}{c}\mathrm{O} \\
\mathrm{SPZ} \\
\mathrm{SAL}+ \\
\mathrm{NaHCO}_{3}\end{array}$ & $\begin{array}{l}93 \\
86 \\
93\end{array}$ & $\begin{array}{r}10.0 \\
9.0 \\
8.0\end{array}$ & $\begin{array}{l}0.54 \\
4.62 \\
1.52\end{array}$ & $\begin{array}{r}5.4 \\
51.4 \\
19.0\end{array}$ & $\begin{array}{r}5.8 \\
60.0 \\
20.4\end{array}$ & & & & & 18.3 & 5.5 & 5.1 & 1.28 & $\begin{array}{l}5.8 \\
5.8 \\
7.0\end{array}$ & $\begin{array}{r}9.0 \\
9.3 \\
14.7\end{array}$ \\
\hline JJ & $\begin{array}{l}23-63 \\
88-128\end{array}$ & $\begin{array}{l}\text { O } \\
\text { SAL } \\
\text { SPZ }\end{array}$ & $\begin{array}{l}130 \\
126 \\
129\end{array}$ & $\begin{array}{l}10.9 \\
10.9 \\
10.9\end{array}$ & $\begin{array}{l}1.16 \\
2.72 \\
1.31\end{array}$ & $\begin{array}{l}10.6 \\
25.0 \\
12.0\end{array}$ & $\begin{array}{r}8.2 \\
20.0 \\
9.3\end{array}$ & 2.9 & 0.20 & 0.26 & 1.35 & $\begin{array}{l}16.1 \\
16.4\end{array}$ & $\begin{array}{l}4.8 \\
4.9\end{array}$ & $\begin{array}{l}6.1 \\
6.4\end{array}$ & $\begin{array}{l}2.36 \\
0.61\end{array}$ & $\begin{array}{l}6.0 \\
6.8 \\
6.4\end{array}$ & $\begin{array}{r}3.1 \\
9.6 \\
15.4\end{array}$ \\
\hline LW & $\begin{array}{c}22-67 \\
102-142\end{array}$ & $\begin{array}{l}\text { O } \\
\text { SAL } \\
\text { SPZ }\end{array}$ & $\begin{array}{r}92 \\
119 \\
96\end{array}$ & $\begin{array}{l}8.4 \\
8.5 \\
8.0\end{array}$ & $\begin{array}{l}0.33 \\
2.10 \\
0.50\end{array}$ & $\begin{array}{r}3.9 \\
24.6 \\
6.3\end{array}$ & $\begin{array}{r}4.2 \\
20.8 \\
6.5\end{array}$ & 2.3 & 0.16 & 0.16 & 0.65 & $\begin{array}{l}18.3 \\
20.8\end{array}$ & $\begin{array}{l}5.5 \\
6.3\end{array}$ & $\begin{array}{l}6.6 \\
6.1\end{array}$ & $\begin{array}{l}1.41 \\
0.44\end{array}$ & & $\begin{array}{r}6.9 \\
8.8 \\
10.5\end{array}$ \\
\hline IB & $\begin{array}{c}23-61 \\
93-113 \\
113-133\end{array}$ & $\begin{array}{l}\text { O } \\
\text { SAL } \\
\text { SPZ } \\
\text { SPZ }\end{array}$ & $\begin{array}{l}124 \\
125 \\
122 \\
124\end{array}$ & $\begin{array}{r}10.6 \\
9.2 \\
9.7 \\
9.7\end{array}$ & $\begin{array}{l}0.42 \\
3.32 \\
1.71 \\
0.97\end{array}$ & $\begin{array}{r}4.0 \\
36.1 \\
17.9 \\
10.0\end{array}$ & $\begin{array}{r}3.2 \\
28.9 \\
14.7 \\
8.3\end{array}$ & $\begin{array}{l}2.2 \\
1.9\end{array}$ & $\begin{array}{l}0.15 \\
0.13\end{array}$ & $\begin{array}{l}0.18 \\
0.16\end{array}$ & $\begin{array}{l}1.11 \\
0.99\end{array}$ & $\begin{array}{l}18.6 \\
19.1 \\
19.1\end{array}$ & $\begin{array}{l}5.6 \\
5.7 \\
5.7\end{array}$ & $\begin{array}{l}7.0 \\
7.1 \\
7.1\end{array}$ & $\begin{array}{l}2.95 \\
0.63 \\
0.45\end{array}$ & $\begin{array}{l}5.4 \\
6.2 \\
6.1 \\
6.2\end{array}$ & $\begin{array}{r}4.7 \\
15.3 \\
14.9 \\
7.5\end{array}$ \\
\hline
\end{tabular}

$* \mathrm{C}=$ clearance (of inulin or urate), $\mathrm{P}=$ plasma concentration, $\mathrm{UV}=$ urinary excretion rate, and $\mathrm{F}=$ filtered load, or $\mathrm{P}_{\text {free }} \times \mathrm{C}_{\mathrm{in}} . \mathrm{All}$ values represent means of 3 or 4 clearance periods.

$\dagger$ Estimated as $2 \%$ of $P_{\text {tots }}$ before and $7 \%$ after SAL infusion.

product, gentisic acid, without appreciable loss of sulfinpyrazone. The first buffer wash removes approximately $96 \%$ of the salicylate present, the second reduces the salicylate to insignificant levels. The absence of salicylate can be tested by measuring the ultraviolet absorption at $303 \mathrm{~m} \mu$, where salicylate has an absorption peak; the absorbance of sulfinpyrazone at this wave length is minimal.

Binding to plasma proteins was determined by equilibrium dialysis at $37^{\circ} \mathrm{C}$ through a Visking membrane

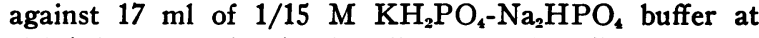
$\mathrm{pH} 7.4$, as previously described for phenylbutazone by Burns and associates (19). In some experiments, the drugs were added in vitro in $1 \mathrm{ml}$ of buffer directly to $5 \mathrm{ml}$ plasma or $5 \mathrm{ml} 5 \%$ albumin in buffer ; ${ }^{2}$ in others, the plasma was from human subjects or dogs previously given sulfinpyrazone, salicylate, or both. After 36 to 48 hours, a sample of the outside phase was tested for leakage with $10 \%$ trichloroacetic acid; then both phases were analyzed. In the experiments with drugs added, the amounts were $0.60 \mathrm{mg}$ of sulfinpyrazone and $12.0 \mathrm{mg}$ of sodium salicylate, with the $\mathrm{pH}$ of the drug solution carefully adjusted to 7.4. In all experiments, the equilibrium

2 Crystalline human albumin, Nutritional Biochemicals Corporation, Cleveland, Ohio. concentration of sulfinpyrazone inside the dialysis bag ranged from 20 to $85 \mathrm{mg}$ per $\mathrm{L}$. Similar procedures were used in experiments on the binding to human albumin of each of the two optically active isomers of sulfinpyrazone, except that $12 \mathrm{mg}$ of sodium salicylate was used.

For determination of how much of the sulfinpyrazone displaced from plasma protein-binding sites by salicylate enters blood cells, $10 \mathrm{ml}$ of blood collected in heparinized, siliconized syringes was delivered into each of three siliconized test tubes. To tube 1 was added $0.6 \mathrm{mg}$ sulfinpy-

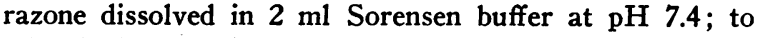
tube 2 (control), a corresponding solution of $2.4 \mathrm{mg}$ sodium salicylate was added; and to tube 3 , a corresponding solution containing both drugs. After incubation for 30 minutes at $37^{\circ} \mathrm{C}$ and centrifugation to separate the plasma, $P_{S p z}$ of tube 1 exceeded that of tube 3 ; the difference represents cell uptake of free sulfinpyrazone in a closed system under the conditions described.

\section{RESULTS}

\section{Experiments in man}

Sulfinpyrazone infused initially, then conjointly with salicylate. Sulfinpyrazone infused at a rate sufficient to maintain $P_{\mathbf{S P Z}}$ at 2.9 to $4.9 \mathrm{mg}$ per 100 

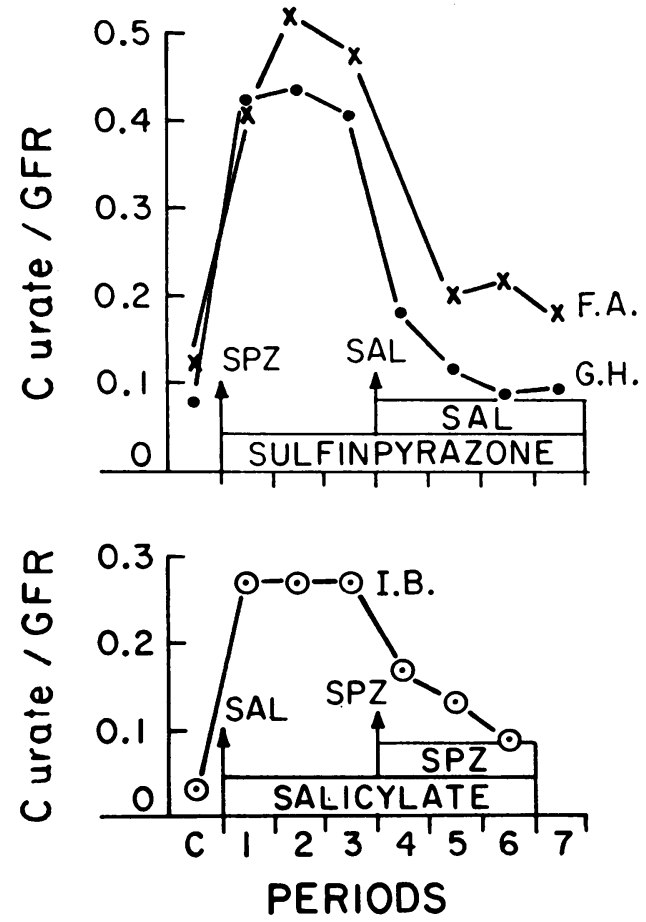

Fig. 1. INFUSION IN MAN OF SULFINPYRAzone AND Salicylate. Top: in GH, the marked increase in $\mathrm{C}_{\text {urate/GFR }}$ effected by sulfinpyrazone (SPZ) was promptly abolished when salicylate (SAL) was also infused. In this instance the urine was acid. In FA, whose urine was alkaline, salicylate also exerted a markedly suppressive effect, but $\mathrm{C}_{\text {urate }} / \mathrm{GFR}$ did not return to control levels. Bottom: in IB, the uricosuric action of salicylate in large dosage was suppressed by concurrent infusion of sulfinpyrazone.

$\mathrm{ml}$ was excreted at a rate of 0.26 to $1.18 \mathrm{mg}$ per minute (in Table I, GH, MK, FA, and ER). The excreted sulfinpyrazone substantially exceeded that filtered at the glomerulus, calculated on the basis of $98 \%$ of $\mathrm{P}_{\mathbf{S P z}}$ bound to plasma proteins (see below), indicating net tubular secretion of the drug: These findings conform to previous experience (20). The usual uricosuric effect of sulfinpyrazone was observed; urinary urate excretion $\left(\mathrm{U}_{\mathbf{u r}} \mathrm{V}\right)$ in $\mathrm{GH}, \mathrm{MK}, \mathrm{FA}, \mathrm{ER}$, and NG (Table I) rose from a mean of 0.97 to $4.96 \mathrm{mg}$ per minute, with a concomitant increase in mean $\mathrm{C}_{\mathrm{ur}} / \mathrm{C}_{\mathrm{in}}$ ratios from 8.5 to $52.1 \%$, indicating inhibition of tubular reabsorption of uric acid.

With the rate of sulfinpyrazone infusion unchanged, sodium salicylate was then also infused at a rate sufficient to maintain high plasma salicylate concentrations $\left(\mathrm{P}_{\mathrm{SAL}}\right), 16.9$ to $22.5 \mathrm{mg}$ per $100 \mathrm{ml}$.
The effects were noteworthy in three respects (Table I). 1) When the urine remained acid ( $\mathrm{GH}$, $\mathrm{MK}), \mathrm{U}_{\mathrm{ur}} \mathrm{V}$ and $\mathrm{C}_{\mathrm{ur}} / \mathrm{C}_{\text {in }}$ fell rapidly to levels near those before infusion of sulfinpyrazone (Figure 1), i.e., the uricosuria produced by sulfinpyrazone was more or less completely abolished; moreover, salicylate evidently also failed to exert any uricosuric effect of its own. 2) When the urine was alkaline (FA), or rendered alkaline by infusion of sodium bicarbonate (ER, NG), $\mathrm{U}_{\mathrm{ur}} \mathrm{V}$ and $\mathrm{C}_{\mathrm{ur}} / \mathrm{C}_{\mathrm{in}}$ declined markedly, but tended to remain above control levels (Figure 1). The plasma concentrations of sulfinpyrazone $\left(\mathrm{P}_{\text {total SPz }}\right)$ declined, from a mean of 3.9 to $2.3 \mathrm{mg}$ per $100 \mathrm{ml}$, a decrease of $41 \%$, without any accompanying rise in sulfinpyrazone excretion. That this decline reflects displacement of plasma protein-bound sulfinpyrazone by salicylate is shown in experiments to be described later. 3) The excretion of free salicylate was less than expected at the prevailing $\mathrm{P}_{\mathrm{SAL}}(12,21)$; in $\mathrm{GH}$ and $\mathrm{MK}$, it averaged only $0.72 \mathrm{mg}$ per minute at acid $\mathrm{pH}\left(\mathrm{C}_{\text {free }} \mathrm{SAL}\right.$, $13 \mathrm{ml}$ per minute), and $1.78 \mathrm{mg}$ per minute at alkaline $\mathrm{pH}$ in $\mathrm{FA}, \mathrm{ER}$, and NG ( $\mathrm{C}_{\text {free } \mathrm{SAL}}, 27 \mathrm{ml}$ per minute). The salicylate filtered at the glomerulus, calculated on the basis of $70 \%$ of $\mathrm{P}_{\mathrm{SAL}}$ bound to plasma proteins, greatly exceeded the salicylate appearing in the urine, whether alkaline or acid, indicating net tubular reabsorption. This contrasts with the usual experience with infusion of salicylate; at urinary $\mathrm{pH} 7.3$ or above, excreted salicylate ordinarily approaches or exceeds filtered salicylate $(12,21)$.

Salicylate infused initially, then conjointly with sulfinpyrazone. In JJ, LW, and IB (Table I), salicylate infused at a rate sufficient to maintain $P_{\mathrm{SAL}}$ at 16.1 to $18.6 \mathrm{mg}$ per $100 \mathrm{ml}$ (about the same plasma levels as in the previous experiments cited in Table I) was excreted at a mean rate of $2.24 \mathrm{mg}$ per minute. This rate of excretion is consistent with prior experience with salicylate infusion in subjects with slightly acid urine (12, 21 ), but much more rapid than in GH and MK, also receiving sulfinpyrazone, and in FA even when the urine was alkaline. The usual uricosuric effect of salicylate in this high dose was noted; $\mathrm{U}_{\mathrm{ur}} \mathrm{V}$ rose from a mean of 0.64 to $2.71 \mathrm{mg}$ per minute, and the mean $\mathrm{C}_{\mathrm{ur}} / \mathrm{C}_{\mathrm{In}}$ from 5.2 to $23.2 \%$, owing to inhibition of tubular reabsorption of uric acid. 
While the salicylate infusion was continued to maintain the same high $\mathrm{P}_{\mathrm{SAL}}$, infusion of sulfinpyrazone was instiuted at about the same rate as in the previous experiments. Again, $\mathrm{U}_{\mathrm{ur}} \mathrm{V}$ and $\mathrm{C}_{\mathrm{ur}} /$ $\mathrm{C}_{\text {in }}$ fell markedly, although somewhat more slowly (Figure 1), toward levels prevailing before the start of the salicylate infusion (mean $\mathrm{U}_{\mathrm{ur}} \mathrm{V}, 1.04$ mg per minute; $\mathrm{C}_{\mathrm{ur}} / \mathrm{C}_{\mathrm{in}} 8.9 \%$ ). The excretion of salicylate also sharply declined, to a mean of $0.52 \mathrm{mg}$ per minute, about the same rate as in the reverse-order experiments in patients with acid urine, with little or no increase in $\mathrm{P}_{\mathrm{SAL}}$. $\mathrm{P}_{\mathrm{SPZ}}$ ranged from 2.0 to $2.9 \mathrm{mg}$ per $100 \mathrm{ml}$ (mean, 2.4 $\mathrm{mg}$ per $100 \mathrm{ml}$ ), lower than levels initially achieved in GH, MK, FA, and ER (mean, 3.9 $\mathrm{mg}$ per $100 \mathrm{ml}$ ) but corresponding to $\mathrm{P}_{\mathrm{SPz}}$ after infusion of salicylate in those subjects. The mean urinary sulfinpyrazone excretion was $1.01 \mathrm{mg}$ per minute.

\section{Corresponding experiments in the dog}

In the initial studies in the dog, drug doses comparable to those in the preceding experiments in man were used, but the results were unrevealing. For example, in the mongrel dog, $100 \mathrm{mg}$ sulfinpyrazone was given to prime and $0.5 \mathrm{mg}$ per minute to sustain; after appropriate collection periods, $0.75 \mathrm{~g}$ sodium salicylate was given to prime and $4 \mathrm{mg}$ per minute to sustain; plasma urate concentration $\left(\mathrm{P}_{\mathrm{ur}}\right)$ was maintained throughout at about $5 \mathrm{mg}$ per $100 \mathrm{ml}$ by continuous uric acid infusion. The mean control $\mathrm{U}_{\mathrm{ur}} \mathrm{V}, 1.75 \mathrm{mg}$ per minute, did not rise after sulfinpyrazone (although the dose was sufficient to cause a rise in

TABLE II

Interactions of sulfinpyrazone (SPZ) and salicylate $(S A L)$ in Dalmatian $(D)$ and non-Dalmatian mongrel $(M)$ dogs*

\begin{tabular}{|c|c|c|c|c|c|c|c|c|c|c|c|c|c|c|c|c|}
\hline \multirow[b]{2}{*}{ Dog } & \multirow[b]{2}{*}{ Period } & \multirow[b]{2}{*}{ Infusion } & \multirow[b]{2}{*}{$\mathrm{C}_{\mathrm{er}}$} & \multicolumn{4}{|c|}{ Urate } & \multicolumn{4}{|c|}{ Sulfinpyrazone } & \multicolumn{4}{|c|}{ Salicylate } & \multirow{2}{*}{$\underset{\text { V§ }}{\text { Urine }}$} \\
\hline & & & & $\mathbf{P}$ & UV & C & $\mathrm{C}_{\mathrm{ur}} / \mathrm{C}_{\mathrm{er}}$ & $P_{\text {total }}$ & Pfreet & $\mathbf{F}$ & UV & Ptotal & $P_{\text {freef }}$ & $F$ & UV & \\
\hline & $\min$ & & $\underset{m i n}{m l /}$ & $\begin{array}{c}m g / \\
100 \mathrm{ml}\end{array}$ & $\underset{\min }{\operatorname{mg} /}$ & $\underset{m i n}{\operatorname{ml}}$ & & \multicolumn{2}{|c|}{$m g / 100 m l$} & \multicolumn{2}{|c|}{$m g / m i n$} & \multicolumn{2}{|c|}{$m g / 100 m l$} & \multicolumn{2}{|c|}{$m g / m i n$} & $m l / m i n$ \\
\hline D-2612 & $\begin{array}{c}45-75 \\
108-138\end{array}$ & $\begin{array}{l}\mathrm{O} \\
\text { SPZ } \\
\text { SAL }\end{array}$ & $\begin{array}{l}48.8 \\
62.2 \\
60.3\end{array}$ & $\begin{array}{l}2.9 \\
3.9 \\
4.8\end{array}$ & $\begin{array}{l}2.14 \\
2.77 \\
3.05\end{array}$ & $\begin{array}{l}73.9 \\
71.0 \\
63.5\end{array}$ & $\begin{array}{l}1.51 \\
1.14 \\
1.05\end{array}$ & $\begin{array}{l}5.9 \\
3.3\end{array}$ & $\begin{array}{l}0.6 \\
0.5\end{array}$ & $\begin{array}{l}0.37 \\
0.31\end{array}$ & $\begin{array}{l}0.39 \\
0.33\end{array}$ & 20.5 & 8.2 & 5.8 & 1.02 & $\begin{array}{r}7.7 \\
13.2 \\
18.9\end{array}$ \\
\hline D-2147 & $\begin{array}{c}45-75 \\
105-135\end{array}$ & $\begin{array}{l}\mathrm{O} \\
\mathrm{SPZ} \\
\mathrm{SAL}\end{array}$ & $\begin{array}{l}51.6 \\
59.2 \\
63.9\end{array}$ & $\begin{array}{l}2.4 \\
3.6 \\
4.5\end{array}$ & $\begin{array}{l}1.65 \\
1.85 \\
2.38\end{array}$ & $\begin{array}{l}68.8 \\
51.5 \\
53.0\end{array}$ & $\begin{array}{l}1.33 \\
0.87 \\
0.83\end{array}$ & $\begin{array}{l}7.4 \\
3.9\end{array}$ & $\begin{array}{l}0.7 \\
0.6\end{array}$ & $\begin{array}{l}0.44 \\
0.40\end{array}$ & $\begin{array}{l}0.56 \\
0.63\end{array}$ & 23.1 & 9.2 & 4.8 & 0.57 & $\begin{array}{r}9.5 \\
12.7 \\
14.7\end{array}$ \\
\hline D-2534 & $\begin{array}{c}50-70 \\
100-130\end{array}$ & $\begin{array}{l}\text { O } \\
\text { SAL }\end{array}$ & $\begin{array}{l}36.0 \\
49.4 \\
50.1\end{array}$ & $\begin{array}{l}3.6 \\
4.9 \\
5.5\end{array}$ & $\begin{array}{l}1.90 \\
2.92 \\
3.01\end{array}$ & $\begin{array}{l}52.8 \\
59.5 \\
54.7\end{array}$ & $\begin{array}{l}1.47 \\
1.21 \\
1.09\end{array}$ & 2.3 & 0.4 & 0.19 & 0.52 & $\begin{array}{l}17.1 \\
19.2\end{array}$ & $\begin{array}{l}6.8 \\
7.7\end{array}$ & $\begin{array}{l}3.7 \\
4.4\end{array}$ & $\begin{array}{l}0.44 \\
0.50\end{array}$ & $\begin{array}{r}8.8 \\
16.5 \\
18.7\end{array}$ \\
\hline D-2147 & $\begin{array}{c}45-75 \\
100-128\end{array}$ & $\begin{array}{l}\text { O } \\
\text { SAL } \\
\text { SPZ }\end{array}$ & $\begin{array}{l}68.0 \\
65.6 \\
49.1\end{array}$ & $\begin{array}{l}4.7 \\
6.9 \\
8.0\end{array}$ & $\begin{array}{l}3.90 \\
4.35 \\
3.83\end{array}$ & $\begin{array}{l}83.0 \\
63.0 \\
47.9\end{array}$ & $\begin{array}{l}1.22 \\
0.96 \\
0.97\end{array}$ & & & & & $\begin{array}{l}27.9 \\
26.0\end{array}$ & $\begin{array}{l}11.2 \\
10.4\end{array}$ & $\begin{array}{l}3.8 \\
4.6\end{array}$ & $\begin{array}{l}1.10 \\
0.51\end{array}$ & $\begin{array}{l}12.9 \\
14.0 \\
12.3\end{array}$ \\
\hline D-2535 & $\begin{array}{l}30-50 \\
80-110\end{array}$ & $\begin{array}{l}\text { SAL } \\
\text { SPZ }\end{array}$ & $\begin{array}{l}53.7 \\
57.1 \\
62.5\end{array}$ & $\begin{array}{l}12.0 \\
11.2 \\
10.7\end{array}$ & $\begin{array}{l}8.18 \\
6.55 \\
5.69\end{array}$ & $\begin{array}{l}68.2 \\
58.5 \\
52.6\end{array}$ & $\begin{array}{l}1.27 \\
1.02 \\
0.84\end{array}$ & & & & & $\begin{array}{l}18.2 \\
20.2\end{array}$ & $\begin{array}{l}7.3 \\
8.0\end{array}$ & $\begin{array}{l}4.2 \\
5.0\end{array}$ & $\begin{array}{l}1.09 \\
0.69\end{array}$ & $\begin{array}{l}6.5 \\
8.4 \\
9.2\end{array}$ \\
\hline M-4302 & $\begin{array}{l}30-60 \\
90-120\end{array}$ & $\begin{array}{c}\text { O } \\
\text { SPZ } \\
\text { SAL }\end{array}$ & $\begin{array}{l}70.0 \\
66.4 \\
72.2\end{array}$ & $\begin{array}{l}3.6 \\
3.6 \\
3.6\end{array}$ & $\begin{array}{l}1.19 \\
1.30 \\
1.72\end{array}$ & $\begin{array}{l}33.1 \\
36.1 \\
47.8\end{array}$ & $\begin{array}{l}0.47 \\
0.54 \\
0.66\end{array}$ & $\begin{array}{l}3.2 \\
1.0\end{array}$ & $\begin{array}{l}0.3 \\
0.2\end{array}$ & $\begin{array}{l}0.22 \\
0.12\end{array}$ & $\begin{array}{l}0.46 \\
0.40\end{array}$ & 17.1 & 6.8 & 4.9 & 1.18 & $\begin{array}{l}5.2 \\
5.2 \\
6.6\end{array}$ \\
\hline M-2509 & $\begin{array}{c}49-69 \\
111-135\end{array}$ & $\begin{array}{l}\mathrm{O} \\
\text { SPZ } \\
\text { SAL }\end{array}$ & $\begin{array}{l}57.1 \\
65.7 \\
76.5\end{array}$ & $\begin{array}{l}2.3 \\
2.9 \\
2.8\end{array}$ & $\begin{array}{l}0.52 \\
1.29 \\
1.89\end{array}$ & $\begin{array}{l}22.6 \\
44.5 \\
67.5\end{array}$ & $\begin{array}{l}0.40 \\
0.68 \\
0.88\end{array}$ & $\begin{array}{l}7.4 \\
3.8\end{array}$ & $\begin{array}{l}0.7 \\
0.6\end{array}$ & $\begin{array}{l}0.49 \\
0.47\end{array}$ & $\begin{array}{l}0.67 \\
0.64\end{array}$ & 19.1 & 7.6 & 4.9 & 0.58 & $\begin{array}{r}5.0 \\
7.5 \\
10.9\end{array}$ \\
\hline M-2508 & $\begin{array}{c}60-80 \\
110-132\end{array}$ & $\begin{array}{l}\stackrel{O}{\text { SPZ }} \\
\text { SAL }\end{array}$ & $\begin{array}{l}53.6 \\
68.4 \\
72.7\end{array}$ & $\begin{array}{l}4.2 \\
3.8 \\
3.3\end{array}$ & $\begin{array}{l}0.51 \\
1.26 \\
1.58\end{array}$ & $\begin{array}{l}12.1 \\
33.2 \\
48.0\end{array}$ & $\begin{array}{l}0.23 \\
0.49 \\
0.66\end{array}$ & $\cdot$ & & & & & & & & $\begin{array}{r}5.4 \\
9.2 \\
11.1\end{array}$ \\
\hline M-2453 & $\begin{array}{c}45-75 \\
105-135\end{array}$ & $\begin{array}{c}\mathrm{O} \\
\text { SPZ } \\
\text { SAL }\end{array}$ & $\begin{array}{l}64.3 \\
69.0 \\
59.0\end{array}$ & $\begin{array}{l}3.6 \\
5.6 \\
6.6\end{array}$ & $\begin{array}{l}1.27 \\
2.45 \\
2.79\end{array}$ & $\begin{array}{l}35.3 \\
43.9 \\
42.3\end{array}$ & $\begin{array}{l}0.55 \\
0.63 \\
0.72\end{array}$ & $\begin{array}{l}4.3 \\
3.4\end{array}$ & $\begin{array}{l}0.4 \\
0.5\end{array}$ & $\begin{array}{l}0.30 \\
0.30\end{array}$ & $\begin{array}{l}0.39 \\
0.36\end{array}$ & 16.4 & 6.6 & 5.9 & 0.48 & $\begin{array}{l}12.0 \\
17.9 \\
17.2\end{array}$ \\
\hline M-2508 & $\begin{array}{r}75-112 \\
145-177\end{array}$ & $\begin{array}{l}\text { O } \\
\text { SAL } \\
\text { SPZ }\end{array}$ & $\begin{array}{l}67.3 \\
63.9 \\
63.5\end{array}$ & $\begin{array}{l}2.5 \\
3.5 \\
5.2\end{array}$ & $\begin{array}{l}1.20 \\
1.74 \\
2.62\end{array}$ & $\begin{array}{l}48.0 \\
49.8 \\
50.4\end{array}$ & $\begin{array}{l}0.72 \\
0.78 \\
0.80\end{array}$ & 3.6 & 0.6 & 0.37 & 0.48 & $\begin{array}{l}14.7 \\
18.0\end{array}$ & $\begin{array}{l}5.9 \\
7.2\end{array}$ & $\begin{array}{l}7.4 \\
5.1\end{array}$ & $\begin{array}{l}1.20 \\
1.31\end{array}$ & $\begin{array}{l}11.5 \\
19.3 \\
23.3\end{array}$ \\
\hline M-2509 & $\begin{array}{c}45-75 \\
105-135\end{array}$ & $\begin{array}{l}\text { O } \\
\text { SAL } \\
\text { SPZ }\end{array}$ & $\begin{array}{l}64.4 \\
74.2 \\
80.5\end{array}$ & $\begin{array}{l}2.3 \\
2.7 \\
3.2\end{array}$ & $\begin{array}{l}0.71 \\
1.22 \\
1.73\end{array}$ & $\begin{array}{l}30.8 \\
45.2 \\
54.0\end{array}$ & $\begin{array}{l}0.48 \\
0.61 \\
0.67\end{array}$ & & & & & $\begin{array}{l}12.4 \\
13.5\end{array}$ & $\begin{array}{l}5.0 \\
5.4\end{array}$ & $\begin{array}{l}3.4 \\
3.9\end{array}$ & $\begin{array}{l}0.85 \\
0.95\end{array}$ & $\begin{array}{r}5.8 \\
10.1 \\
11.8\end{array}$ \\
\hline
\end{tabular}

* $\mathrm{C}_{\mathrm{cr}}=$ creatinine clearance; other abbreviations as in Table I. All values represent means of 3 or 4 clearance periods.

$\dagger$ Estimated as $10 \%$ of $P$ total before and $16 \%$ after $\mathrm{SAL}$ infusion.

Estimated as $40 \%$ of $\mathrm{P}_{\text {total }}$ before and after SPZ infusion.
At these rapid rates of flow, urinary $\mathrm{pH}$ does not vary enough to affect drug excretion appreciably. 


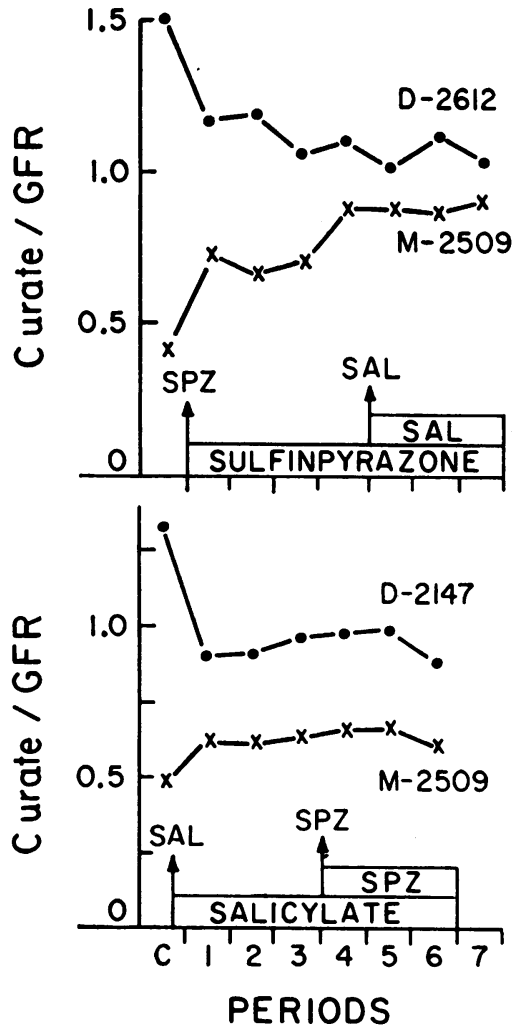

Fig. 2. INFUSION IN DOGS OF SUlfinPyrazone AND SALICYLATE. Top: infusion of sulfinpyrazone caused a modest fall in $\mathrm{C}_{u \text { rate }} / \mathrm{GFR}$ in a Dalmation (D-2612) and a modest rise in a mongrel dog (M-2509); in neither did a superimposed infusion of salicylate elicit a further change. Bottom: similar responses were obtained when the order of infusions was reversed.

man), nor did it decline after salicylate was added to the infusion. This absence of response might have been due, in part, to the shorter biologic half-life of sulfinpyrazone in the dog than in man. Consequently, in the experiments that follow (Table II), the doses of sulfinpyrazone and salicylate administered were larger, sufficient to give $\mathrm{P}_{\mathrm{SPZ}}$ and $\mathrm{P}_{\mathrm{SAL}}$ in the dog comparable to those obtained in man. At these doses, however, GFR and rate of urine flow are apt to increase (Table II), and it was not possible in some experiments to maintain $\mathrm{P}_{\mathrm{ur}}$ in a steady state. Interpretation therefore is difficult, but the data nevertheless clearly indicate that there is no uricosuric response to sulfinpyrazone or salicylate in the Dalmatian coach hound (in which tubular reabsorption of uric acid is defective) and that the uricosuric response in the non-Dalmatian mon- grel dog is much less pronounced than in man.

To consider first the Dalmatian dog, even in impure breeds used in this study, $\mathrm{C}_{\mathrm{ur}} / \mathrm{C}_{\mathrm{er}}$ ratios $>1.0$, indicating net tubular secretion of uric acid, are readily demonstrated when uric acid is infused (Table II). Sulfinpyrazone and salicylate caused no increase in $\mathrm{C}_{\mathrm{ur}} / \mathrm{C}_{\mathrm{cr}}$, which indeed declined somewhat (Figure 2), implying inhibition of tubular secretion of uric acid (14); the mean $\mathrm{C}_{\mathrm{ur}}$ in the five experiments cited in Dalmatian dogs decreased from 69.3 to $60.7 \mathrm{ml}$ per minute, and the mean $\mathrm{C}_{\mathrm{ur}} / \mathrm{C}_{\mathrm{cr}}$ from 1.36 to 1.04 (Table II). As the uric acid filtered at the glomerulus increased, without appreciable subsequent reabsorption in the tubules, the excretion of uric acid tended to rise.

In the Dalmatian dog, when sodium salicylate was added to the initial infusion of sulfinpyrazone, or vice versa, $C_{u r}$ (which did not increase markedly with the initial infusion, as it did in man) did not revert to control levels, as it did in man, but was virtually unaffected (Figure 2.) As in man, however, the addition of salicylate to infusion of sulfinpyrazone resulted in a fall in $\mathrm{P}_{\mathbf{S P Z}}$, unaccompanied by increased elimination of sulfinpyrazone in the urine (Table II).

In the non-Dalmatian mongrel dog, infusion of a uricosuric agent, whether sulfinpyrazone or sodium salicylate, resulted in a small, net rise in uric acid clearance (Figure 2), from a mean of 30.3 to $42.1 \mathrm{ml}$ per minute, and in $\mathrm{C}_{\mathrm{ur}} / \mathrm{C}_{\mathrm{cr}}$, from a mean of 0.47 to 0.62 , in the six experiments cited in Table II. As not in man, the addition of sodium salicylate to an initial infusion of sulfinpyrazone, or vice versa, did not bring about a return of $\mathrm{C}_{\mathrm{ur}}$ and $\mathrm{C}_{\mathrm{ur}} / \mathrm{C}_{\mathrm{cr}}$ to or toward premedication levels, but instead elicited some further increase, to a mean of $51.7 \mathrm{ml}$ per minute and 0.73 , respectively (Table II, Figure 2). As in man, however, addition of sodium salicylate to an initial infusion of sulfinpyrazone effected a prompt fall in plasma sulfinpyrazone levels, without any accompanying increase in the urinary elimination of sulfinpyrazone (Table II). Concurrent infusion of sulfinpyrazone did not seem to affect the renal excretion of salicylate appreciably.

It was not possible to demonstrate in the dog a paradoxical effect of salicylate on uric acid excretion like that in man (12). Thus, in non-Dalmatian mongrel dogs, slow infusion of sodium 
salicylate (4 to $8 \mathrm{mg}$ per minute; total dose, 300 to $500 \mathrm{mg}$ ) either induced no change in $\mathrm{C}_{\mathrm{ur}} / \mathrm{C}_{\mathrm{cr}}$, or caused a modest rise. At $\mathrm{P}_{\mathbf{S A L}}$ varying from 1 to $6 \mathrm{mg}$ per $100 \mathrm{ml}$-levels associated in man with distinct renal retention of uric acid (12) - no retention of uric acid was observed in the dog. Similar experiments in Dalmatian dogs showed only a progressive decline in $\mathrm{C}_{\mathrm{ur}}$ as more salicylate was infused.

\section{Displacement by salicylate of sulfinpyrazone bound to plasma proteins}

In the clearance studies described, a fall in plasma sulfinpyrazone levels, unaccompanied by increased urinary excretion of the drug, was noted consistently in both man and dog when salicylate was injected after sulfinpyrazone. Figure 3 illustrates the prompt, sharp decline in $\mathrm{P}_{\mathrm{SPZ}}$ in a man when, 90 minutes after a single iv injection of $800 \mathrm{mg}$ sulfinpyrazone, a second injection of $3 \mathrm{~g}$ sodium salicylate was given. In the dog, this fall in $P_{\mathbf{S P Z}}$ is even more marked (Figure 3). These results suggest redistribution of sulfinpyrazone as a result of displacement, by salicylate, of sulfinpyrazone bound to plasma proteins.

Equilibrium dialysis showed 98 to $99 \%$ binding of sulfinpyrazone to plasma proteins in man at drug concentrations over the range 20 to $85 \mathrm{mg}$ per $L$ inside the dialysis bag (20), but when salicylate was introduced at concentrations of 100 $\mathrm{mg}$ per $\mathrm{L}$, the plasma protein-bound sulfinpyrazone promptly decreased to approximately $93 \%$. In the dog, 90 to $92 \%$ of the sulfinpyrazone present was bound by plasma proteins, and this was reduced to 84 to $85 \%$ when salicylate was added. In reverse-order experiments, the percentage of plasma protein-bound salicylate was not altered significantly by the addition of sulfinpyrazone in concentrations of $100 \mathrm{mg}$ per L.

The partial displacement of plasma proteinbound sulfinpyrazone by salicylate led to an increased concentration in plasma of free sulfinpyrazone and a small rise in the filtered sulfinpyrazone in man (Table I), which presumably contributed to maintenance of excreted sulfinpyrazone levels after injection of salicylate. Excretion, however, would not account for the fall in plasma concentrations of total sulfinpyrazone, and expansion of the space of distribution is implied. There is some entry into red cells, since addition of salicylate in

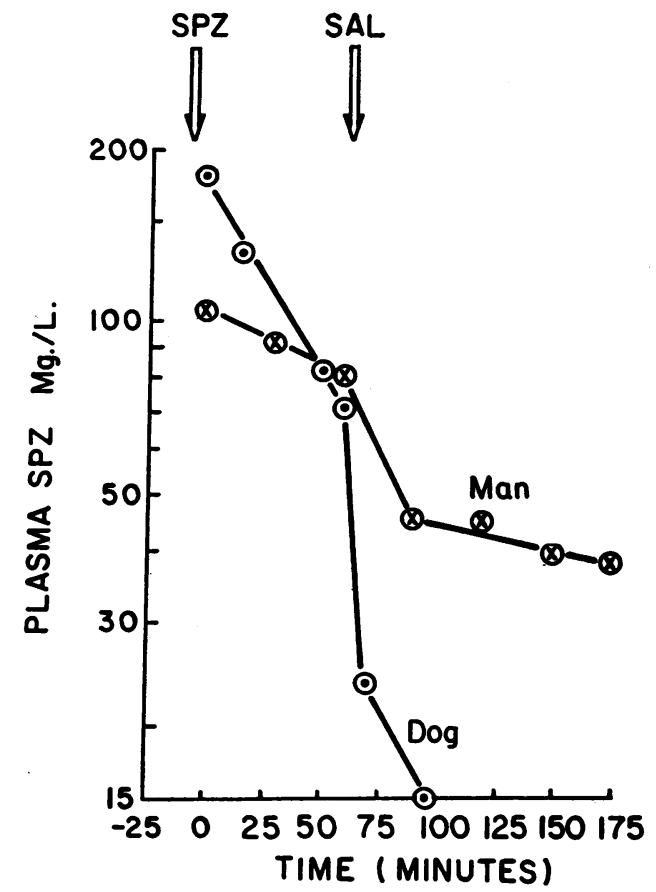

Fig. 3. Semilogarith mic plot Showing Rate of disAPPEARANCE OF SULFINPYRAZONE FROM PLASMA AFTER A SINGLE, RAPID, IV INJECTION OF SULFINPYRAZONE ( 800 MG IN MAN, 500 Mg IN A MONGRel DOG). The rate is more rapid in the dog. A single, rapid, iv injection of sodium salicylate (SAL arrow; $3 \mathrm{~g}$ in man, $2 \mathrm{~g}$ in the dog) precipitously decreased plasma sulfinpyrazone, owing to displacement of protein-bound sulfinpyrazone by salicylate and expansion of the sulfinpyrazone compartment.

vitro reduced the plasma sulfinpyrazone concentration from 80 to about $65 \mathrm{mg}$ per L, without any change in plasma salicylate.

Since sulfinpyrazone is a racemic mixture of two optically active forms (22) and salicylate might displace one of the isomers preferentially, binding experiments with human albumin were carried out with each of the isomers, and with each separately with salicylate. Both isomers were bound to the same degree $(99 \%)$ as the racemic compound at concentrations of $80 \mathrm{mg}$ per L, and this was reduced to $80 \%$ in the presence of salicylate, $800 \mathrm{mg}$ per L.

The two optically active isomers of sulfinpyrazone are metabolized and excreted at similar rates (23). In order to determine whether or not they affect tubular transport of uric acid similarly, a man was given $400 \mathrm{mg}$ of the L-isomer orally in a single dose, and on another day, $400 \mathrm{mg}$ of the $\mathrm{D}$-isomer. 
No significant difference in uricosuric potency between the two isomers, or between them and the racemic compound was found. It would thus appear that the steric differences in the two isomers of sulfinpyrazone play no critical role in their capacity to inhibit tubular reabsorption of uric acid; this seems to be more closely related to the low $\mathrm{pK}_{\mathrm{a}}(2.8)$ that they share (24).

\section{DISCUSSION}

The data show that in man, but not in the dog, salicylate suppresses sulfinpyrazone uricosuria, and sulfinpyrazone suppresses salicylate uricosuria. Since the orbits of sulfinpyrazone $(5,23)$ and salicylate (25-27) in both man and dog meet for transport by plasma proteins and again for renal tubular transport, these were the presumptive sites of drug interaction examined. It is unlikely that competition for conjugative or degradative enzyme systems plays a significant role, particularly under the conditions of rapid loading; moreover, sulfinpyrazone is excreted largely unchanged and in small proportion as the $p$-hydroxylated derivative (23), whereas the proportion of the salicylate that is metabolized appears largely as glycine and glucuronic acid conjugates and as gentisic acid (25, 26).

Uric acid is not bound to plasma proteins (28, 29 ), and so does not compete at this site with salicylate and sulfinpyrazone. Of the plasma salicylate, about $70 \%$ in man is bound to plasma proteins over the range 2 to $35 \mathrm{mg}$ per $100 \mathrm{ml}$ total plasma salicylate (21); in the dog, about $60 \%$ is so bound (30). Investigation of the nature and sites of salicylate binding (31-35) indicates, according to Davison and Smith (33), that the receptors are predominantly $\epsilon$-amino groups of lysine residues of albumin; other groups may also be involved (36). Sulfinpyrazone is more completely bound to plasma proteins, 98 to $99 \%$ in man (20) and about $92 \%$ in the dog (20). Anton (37) showed that at equal concentrations of $100 \mu \mathrm{g}$ per $\mathrm{ml}$, the displacing activity of sulfinpyrazone (mol wt, 404) is greater than that of salicylate (mol wt of sodium salt, 160), at least in competition with sulfonamides for binding to plasma albumin. Davison and Strautz (34) have demonstrated that phenylbutazone analogues, in- cluding sulfinpyrazone, can displace salicylate in vivo and in vitro from plasma protein-binding sites. In the present experiments, however, salicylate was administered in ten times greater doses than sulfinpyrazone (25:1 on a molar basis), and the relative plasma drug concentrations were about $5: 1$. Under these circumstances, salicylate displaced sulfinpyrazone partially from its binding sites on plasma proteins, notably albumin (35), in both man and dog, with only limited entry into red cells. The prompt, accompanying fall in plasma sufinpyrazone is not accounted for by increased urinary excretion as a result of the rise in sulfinpyrazone filtered at the glomerulus, so the sulfinpyrazone compartment must be expanded. As Anton (37) has pointed out, interesting therapeutic potentialities are offered by such displacement of one drug by another, from a physiologically inactive plasma protein-bound state to a free form in greater intracellular concentration.

Sulfinpyrazone and salicylate are presumed to compete likewise for receptor sites at the renal tubules, here also with uric acid, but these interactions have not been clearly defined, and the present study gives only the net effects on tubular transport of the three compounds. Interpretation of these net effects must be speculative as long as concurrent tubular secretion and reabsorption cannot be separately measured, and information about the nature and tubular sites of the transfer mechanisms involved is still fragmentary.

According to the available evidence, the tubules in man and dog actively secrete a variety of weak organic acids $(38,39)$, including salicylate $(12$, $21,26,30)$, sulfinpyrazone (20), and uric acid $(14,29,40,41)$. Tubular secretion of these compounds appears to be competitive (38); this is the interpretation of the renal retention of uric acid, i.e., inhibition of tubular secretion of uric acid, caused by small doses of salicylate in man $(12,42)$. The present study suggests that sulfinpyrazone competes successfully with salicylate for tubular secretion in man, and that this is responsible, in part, for the renal retention of salicylate caused by sulfinpyrazone, whereas salicylate does not cause renal retention of sulfinpyrazone.

Tubular reabsorption of sulfinpyrazone (20) and salicylate $(12,21,26,30,38)$ depends upon 
urinary $\mathrm{pH}$, and so occurs by back-diffusion, whereas reabsorption of uric acid is active and virtually independent of urinary $\mathrm{pH}$ (29). There is no information about the nature of the transport mechanisms for active tubular reabsorption of uric acid, or how and at what cellular sites they are interfered with by uricosuric agents such as sulfinpyrazone and salicylate. However this interference is achieved, whether by a blocking of receptor sites on the tubular cell membrane or otherwise, the present study indicates that in man, particularly when the urine is acid, salicylate virtually completely abolishes the inhibition of tubular reabsorption of uric acid effected by sulfinpyrazone, and vice versa. This action of salicylate is accomplished in the face of unchanged concentrations of sulfinpyrazone in the urine, which would suggest that salicylate somehow blocks the inhibition of active tubular reabsorption of uric acid that is ordinarily effected by sulfinpyrazone in these concentrations. In contrast, suppression of salicylate uricosuria by sulfinpyrazone is associated with a marked reduction in the urinary excretion of unconjugated salicylate, in acid urine, to levels lower than are required to evoke uricosuria (12); this may explain the absence of salicylate uricosuria, despite high plasma salicylate concentrations. The reduced urinary excretion of salicylate caused by sulfinpyrazone implies that tubular reabsorption of salicylate, passive and hence noncompetitive, is unimpeded by sulfinpyrazone, whereas tubular secretion of salicylate, competing with sulfinpyrazone for active transport, may well be diminished. The range of urinary $\mathrm{pH}$ in the present study is small, but it would appear that if the urine is made alkaline to trap salicylic acid, and thus enhance the urinary concentration of salicylate by decreasing the unionized form of the drug, its uricosuric effect is only partially blocked by sulfinpyrazone. Sulfinpyrazone does not block the uricosuric action of probenecid or zoxazolamine, since there is an additive uricosuric response when it is given in combination $(9,43)$.

In the dog, including the Dalmatian coach hound, the magnitude of uric acid excretion regulated by the kidney is far less than in uricase-deficient man, so it is perhaps not surprising that the processes of tubular transfer are muted, even when the plasma uric acid concentration is raised artificially by infusion. Thus, in the mongrel dog the uricosuric effect of sulfinpyrazone and of salicylate is small as compared to that in man, and one drug hardly affects the response to the other; even the paradoxical effect of salicylate on uric acid excretion is not demonstrable. In the Dalmatian dog, neither sulfinpyrazone nor salicylate has a uricosuric action, since tubular reabsorption of uric acid is inherently defective, but both drugs seem to lower the uric acid clearance, apparently by inhibiting tubular secretion of uric acid. The present study gives no clear indication of mutual interference of the tubular secretion of salicylate and sulfinpyrazone in the dog.

\section{SUMMARY}

In man, the uricosuria produced by sulfinpyrazone is suppressed by uricosuric doses of salicylate, and the uricosuria produced by salicylate is likewise suppressed by sulfinpyrazone. In the dog, this antagonism between drugs is not demonstrable, nor could a paradoxical response to salicylate, like that in man, be elicited.

Two sites of interaction between sulfinpyrazone and salicylate were demonstrated, competition for binding sites on plasma proteins and competition for renal tubular transport. In both man and dog, sulfinpyrazone was displaced from binding sites on plasma proteins by salicylate in the concentrations employed. In man, sulfinpyrazone appears to compete successfully with salicylate for tubular secretion, but salicylate apparently blocks the inhibitory effect of sulfinpyrazone on tubular reabsorption of uric acid.

\section{REFERENCES}

1. Yü, T. F., P. G. Dayton, L. Berger, and A. B. Gutman. Interactions of salicylate and sulfinpyrazone in man. Fed. Proc. 1962, 21, 175.

2. Symposium on drug antagonism. Pharmacol. Rev. 1957, 9, 211.

3. Gutman, A. B., and T. F. Yü. Benemid ( $p$-(di-npropylsulfamyl)-benzoic acid) as uricosuric agent in chronic gouty arthritis. Trans. Ass. Amer. Phycns 1951, 64, 279.

4. Pascale, L. R., A. Dubin, and W. S. Hoffman. Therapeutic value of probenecid (Benemid(B) in gout. J. Amer. med. Ass. 1952, 149, 1188. 
5. Burns, J. J., T. F. Yü, A. Ritterband, J. M. Perel, A. B. Gutman, and B. B. Brodie. A potent new uricosuric agent, the sulfoxide metabolite of the phenylbutazone analogue, G-25671. J. Pharmacol. exp. Ther. 1957, 119, 418.

6. Ogryzlo, M. A., and J. Harrison. Evaluation of uricosuric agents in chronic gout. Ann. Rheum. Dis. 1957, 16, 425.

7. Kersley, G. D., E. R. Cook, and D. C. J. Tovey. Value of uricosuric agents and in particular of G.28315 in gout. Ann. rheum. Dis. 1958, 17, 326.

8. Yü, T. F., J. J. Burns, and A. B. Gutman. Results of a clinical trial of G-28315, a sulfoxide analog of phenylbutazone, as a uricosuric agent in gouty subjects. Arthr. and Rheum. 1958, 1, 532.

9. Seegmiller, J. E., and A. I. Grayzel. Use of the newer uricosuric agents in the management of gout. J. Amer. med. Ass. 1960, 173, 1076.

10. Burns, J. J., T. F. Yü, L. Berger, and A. B. Gutman. Zoxazolamine. Physiological disposition, uricosuric properties. Amer. J. Med. 1958, 25, 401.

11. Reed, E. B., T. V. Feichtmeir, and S. G. Craig. Zoxazolamine as a uricosuric agent. I. Acute effects in healthy non-gouty subjects. Arthr. and Rheum. 1961, 4, 533.

12. Yü, T. F., and A. B. Gutman. Study of the paradoxical effects of salicylate in low, intermediate and high dosage on the renal mechanisms for excretion of urate in man. J. clin. Invest. 1959, 38, 1298.

13. Sirota, J. H., T. F. Yü, and A. B. Gutman. Effect of Benemid (p-[di-n-propylsulfamyl]-benzoic acid) on urate clearance and other discrete renal functions in gouty subjects. J. clin. Invest. 1952, 31, 692.

14. Yü, T. F., L. Berger, S. Kupfer, and A. B. Gutman. Tubular secretion of urate in the dog. Amer. J. Physiol. 1960, 199, 1199.

15. Schreiner, G. E. Determination of inulin by means of resorcinol. Proc. Soc. exp. Biol. (N. Y.) 1950, 74, 117.

16. Bonsnes, R. W., and H. H. Taussky. On the colorimetric determination of creatinine by the Jaffe reaction. J. biol. Chem. 1945, 158, 581.

17. Prætorius, E. An enzymatic method for the determination of uric acid by ultraviolet spectrophotometry. Scand. J. clin. Lab. Invest. 1949, 1, 222.

18. Brodie, B. B., S. Udenfriend, and A. F. Coburn. The determination of salicylic acid in plasma. J. Pharmacol. exp. Ther. 1944, 80, 114.

19. Burns, J. J., R. K. Rose, T. Chenkin, A. Goldman, A. Schulert, and B. B. Brodie. The physiological disposition of phenylbutazone (Butazolidin) in man and a method for its estimation in biological material. J. Pharmacol. exp. Ther. 1953, 109, 346.

20. Gutman, A. B., P. G. Dayton, T. F. Yü, L. Berger, W. Chen, L. E. Sicam, and J. J. Burns. A study of the inverse relationship between $\mathrm{pK}_{\mathrm{a}}$ and rate of renal excretion of phenylbutazone analogs in man and dog. Amer. J. Med. 1960, 29, 1017.
21. Gutman, A. B., T. F. Yü, and J. H. Sirota. A study, by simultaneous clearance techniques, of salicylate excretion in man. Effect of alkalinization of the urine by bicarbonate administration; effect of probenecid. J. clin. Invest. 1955, 34, 711.

22. Pfister, R., and F. Häfliger. Uber Derivate und Analoge des Phenylbutazons. IV. Analoge mit schwefelhaltigen Seitenketten. Helv. chim. Acta 1961, 44, 232.

23. Dayton, P. G., L. E. Sicam, M. Landrau, and J. J. Burns. Metabolism of sulfinpyrazone (Anturane) and other thio analogues of phenylbutazone in man. J. Pharmacol. exp. Ther. 1961, 132, 287.

24. Burns, J. J., T. F. Yü, P. Dayton, L. Berger, A. B. Gutman, and B. B. Brodie. Relationship between $\mathrm{pK}_{\mathrm{a}}$ and uricosuric activity in phenylbutazone analogues. Nature (Lond.) 1958, 182, 1162.

25. Kapp, E. M., and A. F. Coburn. Urinary metabolites of sodium salicylate. J. biol. Chem. 1942, 145, 549.

26. Schachter, D., and J. G. Manis. Salicylate and salicyl conjugates: fluorimetric estimation, biosynthesis and renal excretion in man. J. clin. Invest. $1958,37,800$.

27. Wood, P. H. N. Salicylates. Bull. rheum. Dis. 1963, 13, 297.

28. Yü, T. F., and A. B. Gutman. Ultrafiltrability of plasma urate in man. Proc. Soc. exp. Biol. (N. Y.) 1953, 84, 21.

29. Gutman, A. B., and T. F. Yü. A three-component system for regulation of renal excretion of uric acid in man. Trans. Ass. Amer. Phycns 1961, 74, 353.

30. Weiner, I. M., J. A. Washington, II, and G. H. Mudge. Studies on the renal excretion of salicylate in the dog. Bull. Johns Hopk. Hosp. 1959, $105,284$.

31. Goldstein, A. The interaction of drugs and plasma proteins. Pharmacol. Rev. 1949, 1, 102.

32. Reynolds, R. C., and L. E. Cluff. Interaction of serum and sodium salicylate: changes during acute infection and its influence on pharmacological activity. Bull. Johns Hopk. Hosp. 1960, 107, 278.

33. Davison, C., and P. K. Smith. The binding of salicylic acid and related substances to purified proteins. J. Pharmacol. exp. Ther. 1961, 133, 161.

34. Davison, C., and R. L. Strautz. The effect on the distribution and excretion of salicylate by drugs displacing that compound from plasma binding sites. Pharmacologist 1961, 4, 81.

35. Stafford, W. L. The binding by bovine plasma and plasma fractions of salicylic acid and some of its 3-alkyl analogues. Biochem. Pharmacol. 1962, 11, 685.

36. Sterling, K., P. Rosen, and M. Tabachnick. Equilibrium dialysis studies of the binding of thyroxine by human serum albumin. J. clin. Invest. 1962, 41, 1021.

37. Anton, A. H. A drug-induced change in the distribution and renal excretion of sulfonamides. $\mathrm{J}$. Pharmacol. exp. Ther. 1961, 134, 291. 
38. Weiner, I. M., K. D. Garlid, J. A. Romeo, and G. H. Mudge. Effects of tubular secretion and reabsorption on titration curves of tubular transport. Amer. J. Physiol. 1961, 200, 393.

39. Giebisch, G. Kidney, water and electrolyte metabolism. Ann. Rev. Physiol. 1962, 24, 357.

40. Gutman, A. B., T. F. Yü, and L. Berger. Tubular secretion of urate in man. J. clin. Invest. 1959, 38, 1778.
41. Lathem, W., B. B. Davis, and G. P. Rodnan. Renal tubular secretion of uric acid in the mongrel dog. Amer. J. Physiol. 1960, 199, 9.

42. Yü, T. F., and A. B. Gutman. Paradoxical retention of uric acid by uricosuric drugs in low dosage. Proc. Soc. exp. Biol. (N. Y.) 1955, 90, 542.

43. Yü, T. F., and A. B. Gutman. Renal interactions of drugs affecting urate excretion in man. Pharmacologist 1959, 1, 53. 